\title{
Correction to: Techniques to Avoid Complications of Atrial Fibrillation Ablation
}

Nachiket M. Apte, MBBS

Amit Shrestha, MBBS

Raghuveer Dendi, $M D^{*}$

\section{Address}

"The Department of Cardiovascular Medicine, University of Kansas Medical Center, Medical Office Pavilion, 5th Floor, Suite 5200, Mailstop 1032, Kansas City, KS, 66160, USA

Email: rdendi@kumc.edu

Published online: 8 0ctober 2020

(C) Springer Science+Business Media, LLC, part of Springer Nature 2020

The online version of the original article can be found at https://doi.org/10.1007/s11936-020-00834-w

Correction to: Curr Treat Options Cardio Med (2020) 22:31 https://doi.org/10.1007/s11936-020-00834-w

In the recently published review "Techniques to Avoid Complications of Atrial Fibrillation Ablation," the following author name was inadvertently misspelled as Amit Shreshta. The correct spelling of the author's name is: Amit Shrestha as shown above.

\section{Publisher's Note}

Springer Nature remains neutral with regard to jurisdictional claims in published maps and institutional affiliations. 